\title{
Provenance Analysis of Lower Palaeozoic Siliciclastic Rocks of Southwestern Iberia (Ossa-Morena Zone): Distal Shelf Deposition on the North Gondwana Passive Margin
}

\author{
M. F. Pereira, M. Chichorro, C. Lopes, A. M. R. Solá, J. B. Silva, \\ M. Hofmann and U. Linnemann
}

\begin{abstract}
U}-\mathrm{Pb}$ dating of detrital zircons from the lower Palaeozoic siliciclastic rocks of southwestern Iberia (the Ossa-Morena Zone or OMZ: comprising the Fatuquedo, Ossa, Colorada, and Terena formations) shows that sedimentation during the middle-late Cambrian to Early Devonian was marked by slight variations in the source areas, involving the denudation of crustal blocks with similar zircon-forming events typical of North Gondwana and the absence of volcanism younger than ca. $470 \mathrm{Ma}$. The potential source areas of the middle-upper Cambrian to Lower Devonian sediments of the basins of the OMZ could be the Neoproterozoic basement of the OMZ (the Série Negra) intruded by Cambrian and Early Ordovician plutonic rocks, and/or the lower Palaeozoic sedimentary sequences of the OMZ with Cambrian and Early Ordovician volcanics. In the oldest siliciclastic rocks, the most relevant populations of detrital zircons have Cryogenian and Ediacaran ages (the Ossa and Fatuquedo formations). Futhermore, in the youngest siliciclastic rocks, in addition to Cryogenian and Ediacaran zircon grains there are relevant clusters of Cambrian and Tonian ages (the Colorada Formation). Cambrian and Ordovician zircon ages found in the Lower Devonian greywackes (the Terena Formation) suggest intense denudation of the OMZ during
\end{abstract}

M. F. Pereira $(\bowtie)$

IDL, Departamento de Geociências, ECT, Universidade de Évora, Évora, Portugal e-mail: mpereira@uevora.pt

M. Chichorro · C. Lopes

CICEGE, Departamento de Ciências da Terra, Faculdade de Ciências e Tecnologia, Universidade Nova de Lisboa, 2829-516 Caparica, Portugal

e-mail: ma.chichorro@fct.unl.pt

A. M. R. Solá

Unidade de Geologia, LNEG, Lisbon, Portugal

J. B. Silva

Departamento de Geologia, Faculdade de Ciências, Universidade de Lisboa, Lisbon, Portugal

M. Hofmann · U. Linnemann

Senckenberg Naturhistorische Sammlungen Dresden, Dresden, Germany

R. Rocha et al. (eds.), STRATI 2013, Springer Geology,

DOI: 10.1007/978-3-319-04364-7_141, ㄷ Springer International Publishing Switzerland 2014 
the Early Devonian. No evidence was found of sources outside North Gondwana. The lack of zircon-forming events younger than ca. $470 \mathrm{Ma}$ seems to indicate that the middle-upper Cambrian to Lower Devonian siliciclastic rocks of southwestern Iberia were deposited on a distal shelf of the North Gondwana passive margin related to the opening of the Rheic Ocean and in the absence of magmatic activity.

Keywords U-Pb detrital zircon geochronology - Middle-Upper Cambrian • Ordovician • Lower Devonian • Rheic Ocean

The Ossa-Morena Zone (OMZ) is a peri-Gondwanan terrane that records, over the interval ca. 550 to $400 \mathrm{Ma}$, the transition from an active margin with the formation of Neoproterozoic magmatic arcs (the Cadomian orogeny; Linnemann et al. 2008; Pereira et al. 2011, 2012) to a passive margin with the development of early Palaeozoic basins dominated by siliciclastic deposition on a distal shelf (Robardet and Gutierrez-Marco 2004) (Fig. 1). The formation of the lower Palaeozoic stratigraphy began with siliciclastic and carbonate deposition related to the evolution of a Cambrian-Ordovician intracontinental rift with significant magmatic activity (Chichorro et al. 2008; Sanchez-Garcia et al. 2010; Pereira et al. 2012). Later, sedimentation changed to a passive margin setting, without significant magmatism, from ca. 470 to ca. 400 Ma (Robardet and Gutierrez-Marco 2004). Doubts remain about the existence of upper Cambrian rocks in the OMZ, but recently rhyolites of the Estremoz Anticline (Portugal) have been dated at ca. $500 \mathrm{Ma}$ (Pereira et al. 2012). During the middle-late(?) Cambrian to Early Devonian, sedimentation in the OMZ was essentially siliciclastic (with few Ordovician, Silurian, and Devonian limestones) and typically marine with sandstones and shales preserving trilobites, bivalves, ostracods, brachiopods, graptolites, bryozoans, echinoderms, corals, orthoconic nautiloids, chitinozoans, spores, acritarchs, and conodonts (Robardet and Gutierrez-Marco 2004 and references therein). The CambrianOrdovician to Lower Devonian stratigraphy of the OMZ is well preserved in the Valle and Cerrón del Hornillo synclines and the Venta del Ciervo area (Spain) and in the Barrancos-Ensinasola area (Portugal and Spain), where samples of siliciclastic rocks were collected for establishing U-Pb geochronology.

In the Barrancos-Ensinasola area, the middle-upper Cambrian to Lower Devonian stratigraphy includes (Delgado 1910; Oliveira et al. 1991; Piçarra 2000): (1) sandstones and shales of the Ossa and Fatuquedo formations (middle-upper Cambrian); (2) shales of the Barrancos Formation (Lower-Upper Ordovician); (3) psammites and quartzites of the Colorada Formation (Upper Ordovician-lower Silurian); (4) black shales and cherts of the "Xistos com Nódulos" Formation (lower-upper Silurian); (5) shales and sandstones of the "Xistos Raiados" Formation (upper Silurian-Lower Devonian), which includes a member consisting of shales with limestone lenses (Russianas Formation, Perdigão et al. 1982); and (6) shales, greywackes, and conglomerates of the Terena Formation (Lower Devonian).

Coarse-medium-grained siliciclastic rocks of the Ossa, Fatuquedo, Colorada, and Terena formations were sampled for geochronological analysis. U-Pb-dating 
of detrital zircons indicates that no significant variations occur in the sources of the lower Palaeozoic siliciclastic rocks of southwestern Iberia. In the sandstones of the Ossa and Fatuquedo formations, which are considered to be middle-upper Cambrian stratigraphic equivalents, the youngest detrital zircons found are dated at early Cambrian (ca. $529 \mathrm{Ma}$, Fatuquedo Formation) to Ediacaran (ca. $551 \mathrm{Ma}$, Ossa Formation). The most significant population of detrital zircons is Neoproterozoic (Cryogenian, ca. 650-640 Ma, the most important; and Ediacaran, ca. 599-548 Ma). There are some Palaeoproterozoic ages, and a few Archaean and Tonian, with Mesoproterozoic ages being almost absent $(<1 \%)$. In quartzite of the Colorada Formation (Upper Ordovician-lower Silurian), the youngest detrital zircons found are Cambrian (ca. $532 \mathrm{Ma}$ and ca. $501 \mathrm{Ma}$ ). The most significant population is Neoproterozoic (Cryogenian, ca. $660 \mathrm{Ma}$; Ediacaran, ca. $544 \mathrm{Ma}$; and Tonian, ca. $959 \mathrm{Ma}$ and ca. $879 \mathrm{Ma}$ ). There are some Mesoproterozoic and Palaeoproterozoic ages and a few Archaean grains. The presence of Tonian zircons is distinctive when compared with the Ediacaran Série Negra succession and the Cambrian formations (Pereira et al. 2011, 2012; this study). In the greywackes of the Terena Formation (Lower Devonian), the youngest detrital zircons found are Early Ordovician (ca. $485 \mathrm{Ma}$ and ca. $478 \mathrm{Ma}$ ). The most significant detrital zircon population is early Cambrian (ca. $514 \mathrm{Ma}$ ) followed by Neoproterozoic (Ediacaran, ca. $603 \mathrm{Ma}$ ) and Ordovician (ca. $478 \mathrm{Ma}$ ). There are some Palaeoproterozoic and a few Tonian grains.

The results obtained indicate source areas characterized by zircon-forming events with North Gondwanan affinity: (1) Palaeoproterozoic and Archaean ages with an absence or near-absence of Mesoproterozoic ages (West African Craton zircon-forming events); (2) Neoproterozoic ages (Cadomian-Avalonian and PanAfrican zircon-forming events); and (3) Cambrian and Early Ordovician ages (zircon-forming events related to rifting on the Gondwana margin that led to the opening of the Rheic Ocean).

In conclusion, the source areas of the middle-upper Cambrian to Lower Devonian siliciclastic rocks may be related to the Neoproterozoic basement of the OMZ (the Série Negra succession) intruded by Cambrian and Early Ordovician plutonic rocks, and to the lower Palaeozoic sedimentary sequences of the OMZ with Cambrian and Early Ordovician volcanics. In the oldest siliciclastic rocks, Cryogenian and Ediacaran detrital zircons are dominant (the Ossa and Fatuquedo formations), whereas the youngest samples contain Cryogenian and Ediacaran grains but also include relevant age clusters of Cambrian and Tonian ages (the Colorada Formation) and of Cambrian and Ordovician ages (the Terena Formation). These data indicate that, during the middle-late Cambrian, denudation occurred on the Cadomian basement in the absence of early Cambrian magmatic rocks. Subsequently, during the Ordovician-Silurian, exposed outcrops of Cadomian basement included Cambrian magmatic rocks and a source containing grains from Tonian zircon-forming events. The occurrence of detrital zircons with Neoproterozoic (ca. $603 \mathrm{Ma}$ ), Cambrian (ca. $514 \mathrm{Ma}$ ), and Ordovician (ca. $478 \mathrm{Ma})$ ages in the Terena greywackes suggests that the OMZ Cadomian basement in the presence of Cambrian-Ordovician magmatic rocks underwent intense 

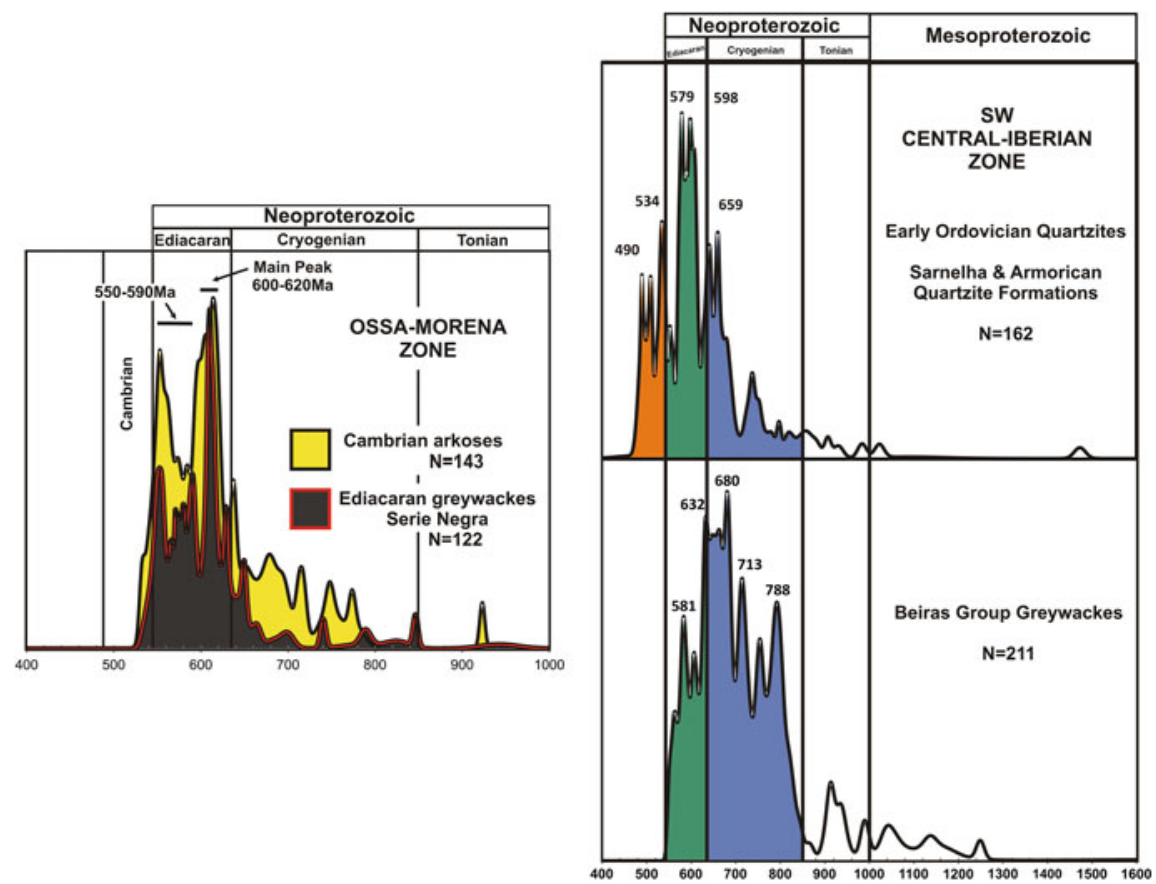

Fig. 1 Middle Cambrian-Lower Devonian stratigraphy of the Ossa-Morena Zone with samples location (Adapted from Robardet and Gutierrez-Marco 2004; Pereira et al. 2012)

denudation during the Early Devonian. No evidence was found for sources outside North Gondwana. The lack of zircon-forming events younger than ca. $470 \mathrm{Ma}$ suggests that the middle-upper Cambrian to Lower Devonian siliciclastic rocks of southwestern Iberia were deposited on a distal shelf of the North Gondwana passive margin related to the opening of the Rheic Ocean and in the absence of magmatic activity.

Acknowledgments This paper is a contribution to research projects GONDWANA-PTDC/CTEGIX/110426/2009 and GOLD- PTDC/GEO-GEO/2446/2012 funded by Fundação para a Ciência e Tecnologia (Portugal) and to IGCP projects 574 "Bending and bent orogens, and continental ribbons" and 597 "Amalgamation and breakup of Pangaea: the type example of the supercontinent cycle" (UNESCO-IUGS). It is a contribution to project PEst-OE/CTE/UI4073/2014.

\section{References}

Chichorro, M., Pereira, M. F., Díaz-Azpiroz, M., Williams, I. S., Fernández, C., Pin, C., et al. (2008). Cambrian ensialic rift-related magmatism in the Ossa-Morena Zone (Évora-Aracena metamorphic belt, SW Iberian Massif): $\mathrm{Sm}-\mathrm{Nd}$ isotopes and SHRIMP zircon U-Th- $\mathrm{Pb}$ geochronology. Tectonophysics, 461, 91-113. doi:10.1016/j.tecto.2008.01.008. 
Delgado, J. F. N. (1910). Terrains Paléozoïques du Portugal. Etude sur les fossiles des Schistes à Néréites de San Domingos et des Schistes à Néréites et à Graptolites de Barrancos. Mémoire de la Commission du Service Géologique du Portugal, Lisboa (p. 68).

Linnemann, U., Pereira, M. F., Jeffries, T., Drost, K., \& Gerdes, A. (2008). Cadomian Orogeny and the opening of the Rheic Ocean: New insights in the diacrony of geotectonic processes constrained by LA-ICP-MS U-Pb zircon dating (Ossa-Morena and Saxo-Thuringian Zones, Iberian and Bohemian Massifs). Tectonophysics, 361, 21-43.

Oliveira, J. T., Oliveira, V., \& Piçarra, J. M. (1991). Traços gerais da evolução tectonoestratigrafica da Zona de Ossa Morena em Portugal. Cuadernos Laboratorio Xeologico Laxe, 16, 221-250.

Perdigão, J. C., Oliveira, J. T., \& Ribeiro, A. (1982). Notícia explicativa da folha 44-B (Barrancos). Carta Geológica de Portugal na escala 1:50 000. Lisboa: Serviços Geológicos de Portugal.

Pereira, M. F., Chichorro, M., Solá, A. R., Silva, J. B., Sánchez-García, T., \& Bellido, F. (2011). Tracing the Cadomian magmatism with detrital/inherited zircon ages by in situ U-Pb SHRIMP geochronology (Ossa-Morena Zone, SW Iberian Massif). Lithos, 123, 204-217. doi:10.1016/j.lithos.2010.11.008.

Pereira, M. F., Solá, A. R., Chichorro, M., Lopes, L., Gerdes, A., \& Silva, J. B. (2012). NorthGondwana assembly, break up and paleogeography: $\mathrm{U}-\mathrm{Pb}$ isotope evidence from detrital and igneous zircons of Ediacaran and Cambrian rocks of SW Iberia (Estremoz Anticline). Gondwana Research, 22(3-4), 866-881. doi:10.1016/j.gr.2012.02.010.

Piçarra, J. M. (2000). Estudo estratigráfico do sector de Estremoz-Barrancos, Zona de Ossa Morena, Portugal. DoctoralThesis, Universidade de Évora, $95+173$ (unpublished).

Robardet, M., \& Gutierrez-Marco, J. C. (2004). The Ordovician, Silurian and Devonian sedimentary rocks of the Ossa-Morena Zone (SW Iberian Peninsula, Spain). Journal of Iberian Geology, 30, 73-92.

Sánchez-García, T., Bellido, F., Pereira, M. F., Chichorro, M., Quesada, C., Pin, C., et al. (2010). Rift related volcanism predating the birth of the Rheic Ocean (Ossa-Morena Zone, SW Iberia). Gondwana Research, 17(2-4), 392-407. 